\title{
Oil Prices and Stock Market Anomalies
}

\author{
Muhammad A. Cheema \\ School of Accounting, Finance and Economics \\ University of Waikato \\ Hamilton, New Zealand \\ Email: muhammad.cheema@waikato.ac.nz
}

Frank Scrimgeour

School of Accounting, Finance and Economics

University of Waikato

Hamilton, New Zealand

Email: frank.scrimgeour@waikato.ac.nz 


\title{
Oil Prices and Stock Market Anomalies
}

\begin{abstract}
This paper examines the relationship between oil prices and stock market anomalies in China, the largest oil importer country in the world. Prior literature documents both a positive and negative relationship between oil prices and the stock market. The explanation of a positive relationship is supported by the argument that rising oil prices are interpreted as a positive signal by investors. Consequently, rising oil prices lead stock prices above their fundamental values and that they subsequently correct. Therefore, we hypothesise that stock market anomalies are stronger following rising oil prices since returns associated with anomalies reflect mispricing. The results, consistent with the hypothesis, show stronger return predictability for individual anomalies following an increase in oil prices than for a decrease in oil prices. The results are even stronger once we construct a mispricing score based on composite mispricing of all the anomalies.
\end{abstract}

JEL Classification Code: G14, G15, Q43

Keywords: oil prices; stock market anomalies; mispricing score; Chinese stock market 


\section{Introduction}

"Falling oil prices can be interpreted by investors as bad news, as they expect falling economic activity, and rising oil prices can be seen as a good signal of a prospering economy. That is, the oil price changes positively influence stock returns through investor expectations."(You, Guo, Zhu and Tang, 2017, p. 11)

Several studies have examined the relationship between the crude oil prices and aggregate stock returns. However, there is no consensus whether the relationship is positive or negative. A large body of the literature has found a negative impact of oil prices on aggregate stock returns, i.e., an increase (decrease) in oil prices decreases (increases) stock prices (e.g. Jones and Kaul, 1996, Sadorsky, 1999, Kling, 1985, Gjerde and Saettem, 1999, Papapetrou, 2001, Basher and Sadorsky, 2006, Basher, Haug and Sadorsky, 2012, Driesprong, Jacobsen and Maat, 2008, Park and Ratti, 2008, Chen, 2010, Filis, 2010). The proponents of a negative relationship suggest that higher oil prices increase the cost of production which would result in lower earnings and dividends and, hence reduces stock prices. In contrast, a few studies have documented a positive relationship (Narayan and Narayan, 2010, Zhu, Li and Yu, 2011, Zhu, Li and Li, 2014, Silvapulle, Smyth, Zhang and Fenech, 2017, Zhu, Guo, You and Xu, 2016, Kilian and Park, 2009). ${ }^{1}$ The explanation of a positive relationship is supported by the suggestion that rising oil prices can be interpreted as a positive signal by investors in a prospering economy (e.g. Kilian and Park, 2009, Kollias, Kyrtsou and Papadamou, 2013). ${ }^{2}$ Consequently, increase in oil prices would lead to higher stock prices and, hence overpricing that would be subsequently corrected once the fundamentals are revealed.

In another strand of the literature, Stambaugh, Yu and Yuan (2012) suggest that the primary form of mispricing is overpricing since based on Miller's (1977) argument short-sale

\footnotetext{
${ }^{1}$ See Smyth and Narayan (2018) for an excellent review on the impact of oil prices on the stock market. ${ }^{2}$ There are a few studies that found mixed or no relationship between oil prices and stock returns (e.g. Huang, Masulis and Stoll, 1996, Cong, Wei, Jiao and Fan, 2008, Apergis and Miller, 2009, Miller and Ratti, 2009).
} 
restrictions limit rational investors ability to sell overpriced securities but not to buy underpriced securities. Stambaugh et al. (2012) show that all the 11 anomalies used in their paper are stronger following high sentiment where overpricing is more prevalent than underpricing suggesting that anomalies are driven by overpricing. Therefore, we contend that if the increase in oil prices is interpreted as a positive signal by investors or as a sign of the prospering economy, then anomalies should be stronger following an increase in oil prices since overpricing is more prevalent when investors are optimistic. Consequently, anomalies should be weaker following a decline in oil prices where underpricing is more prevalent than overpricing.

In this paper, we examine the impact of oil prices on stock market anomalies in China. We focus on China due to three reasons. First, the positive impact of crude oil price on stock market is widely documented for Chinese stock markets (see for example, Zhu et al., 2016, Zhang and Chen, 2011, Li, Zhu and Yu, 2012), whereas there is a scant evidence available on the positive impact of crude oil price on the U.S. and European stock markets. Therefore, it is essential to examine whether the positive relationship between oil prices and stock returns leads to anomalous returns in China.

Second, oil imports have consistently increased in China since it first emerged as a net importer of crude oil in 1993 (e.g., Leung, 2011). China became the largest consumer of crude oil in 2003 and largest crude oil importer in 2017. Consequently, as the largest oil importer and consumer, China is important in determining the global oil demand and price (see for details, Datta and Vigfusson, 2017, Hamilton, 2009). Therefore, an increase in global oil prices could be an indication of rising oil consumption in China due to economic expansion which would be interpreted as a positive signal by Chinese investors.

Third, there is a little evidence available on stock market anomalies in China despite the fact that China is the second largest economy in the world and the Chinese stock market 
is the second largest in the world. The existing evidence on stock market anomalies in China suggests a weaker anomaly effect in Chinese stock markets relative to the U.S. stock markets (e.g. Chen, Kim, Yao and Yu, 2010, Jacobs, 2016). Therefore, exploring the association between oil prices and anomaly returns in China will not only explain the impact of oil prices on the stock market but will also provide an out-of-sample test for the anomalies discovered in the U.S. market.

Following the literature (e.g. Stambaugh et al., 2012, Lu, Stambaugh and Yuan, 2017, Stambaugh, Yu and Yuan, 2015, Jacobs, 2016), we chose 12 anomalies, namely, net stock issues, composite equity, accruals, net operating assets, momentum, gross profitability, asset growth, return on assets, investment to assets, maximum daily return, idiosyncratic risk, and low volatility. Furthermore, following Stambaugh et al. (2015) we construct a mispricing score based on the composite mispricing of all the 12 anomalies since a mispricing score is more likely to provide stronger evidence of mispricing than single anomalies. For each anomaly, we take a long (short) position in underpriced (overpriced) stocks. Thus, the return difference between the long and short position (long-short) shows the return predictability of each anomaly.

We find that six out of 12 anomalies produce positive and statistically significant equal-weighted (EW) long-short returns, and seven anomalies produce positive and significant Fama-French risk-adjusted alpha (alpha). The valued-weighted (VW) long-short returns are positive and significant only for three anomalies; however, alpha is positive and significant for six anomalies. The long-short returns of anomalies are consistent with Jacobs (2016) who show that the anomalies are weak in China relative to the U.S. and other developed markets. However, stocks sorted on mispricing score generates positive and significant long-short returns and alpha which shows that the mispricing is prevalent in the Chinese stock market. Most importantly, we find that anomalies are stronger following rising 
oil prices than falling oil prices that agree with our suggestion. Furthermore, we find that the long-short return sorted on mispricing score are positive and significant only following rising oil prices that support the suggestion that an increase in oil prices enhances investors' expectations that results in overpriced stocks markets.

Our study adds two important contributions to the literature. First, to the best of our knowledge, we are the first to study the mispricing score of Stambaugh et al. (2015) in China. Therefore, we complement the growing literature that shows that mispricing scores provide stronger evidence of mispricing than single anomalies (e.g. Jacobs, 2016, Stambaugh et al., 2012, Lu et al., 2017, Stambaugh et al., 2015). Second, our findings provide strong empirical support to the suggestion that rising oil prices are interpreted as a positive signal by investors in a prospering economy.

The rest of the paper is organised as follows. Section 2 describes our data and methods. Section 3 presents the baseline results. Section 4 examines the impact of oil returns on anomalies. Section 5 provides robustness tests, and the last section concludes the paper.

\section{Methods and Data}

\subsection{Anomalies, Mispricing Score and Long-Short Strategies}

This research analyses 12 anomalies and estimates a mispricing score based on the composite mispricing of all the 12 anomalies through time. Following Lu et al. (2017), Stambaugh, Yu and Yuan (2014, 2012, 2015) and Jacobs (2016), we consider the following 12 anomalies. $^{3}$

1. Net Stock Issues (Ritter, 1991, Loughran and Ritter, 1995)

\footnotetext{
${ }^{3}$ As in Lu et al. (2017), we do not include distress and O-score anomalies because of data limitations. Furthermore, we examine three additional anomalies, namely maximum daily return, idiosyncratic risk and low volatility.
} 
2. Composite Equity (Ritter, 1991, Loughran and Ritter, 1995, Daniel and Titman, 2006)

3. Accruals (Dechow, Sloan and Sweeney, 1995, Sloan, 1996)

4. Net operating assets (Hirshleifer, Hou, Teoh and Zhang, 2004)

5. Momentum (Jegadeesh and Titman, 1993)

6. Gross profitability (Novy-Marx, 2013)

7. Asset growth (Cooper, Gulen and Schill, 2008)

8. Return on assets (Fama and French, 2006)

9. Investment to assets (Titman, Wei and Xie, 2004, Xing, 2007)

10. Maximum daily return (Bali, Cakici and Whitelaw, 2011)

11. Idiosyncratic risk (Ang, Hodrick, Xing and Zhang, 2006)

12. Low volatility (Blitz and van Vliet, 2007)

The detailed description of these anomalies is provided in Appendix A.

We estimate the daily and monthly stock returns, adjusted for dividends, from the stock return index (RI). For each anomaly, we sort stocks into quintiles and take long (short) position in underpriced (overpriced) stocks. ${ }^{4}$ For example, for the net stock issues anomaly, we buy (sell) stocks with the lowest (highest) net stock issues.

Following Stambaugh et al. (2015), we construct a mispricing score based on the composite mispricing of all the 12 anomalies. The mispricing score provides two major benefits. First, the mispricing score diversifies away noise related to the individual anomalies. Second, the mispricing score is more likely to provide stronger evidence of mispricing since it is based on the composite mispricing of all the 12 anomalies.

\footnotetext{
${ }^{4}$ We use quintile portfolios since Chinese stock markets have a relatively lower number of stocks compared to the U.S. stock markets.
} 
To construct the mispricing score, first, we rank stocks based on each anomaly where the lowest (highest) rank is assigned to the most underpriced (overpriced) stocks. Second, we standardise the ranks in each month $t$ based on each individual anomaly to have a zero mean and unit variance. Third, we compute the mispricing score as the arithmetic average of its anomaly ranks. We require at least six individual anomalies to construct the mispricing for each month. ${ }^{5}$ Fourth, we standardise the mispricing score to have zero mean and unit variance. Finally, we rank stocks into quintiles in each month $t$ based on their mispricing score and buy (sell) stocks in the lowest (highest) quintile.

Apart from raw returns, we also calculate Fama-French risk-adjusted returns of the long-short return in each month $t$ as

$$
L S_{t}^{a d j}=L S_{t}-\beta_{m} \cdot R M F T_{t}-\beta_{s} \cdot S M B_{t}-\beta_{h} \cdot H M L_{t}
$$

where RMRF is the excess value-weighted market return of A-shares over the 30-day interbank offer rate, SMB is the small-minus-big size factor, and HML is the high-minus-low book-to-market factor. ${ }^{6} \beta_{m}, \beta_{s}$ and $\beta_{h}$ are the estimated loadings obtained from the time-series regression of the LS returns on the Fama-French (FF) risk factors plus a constant. The details for the construction of RMRF, SMB and HML factors are provided in Appendix C.

\subsection{Data}

The analysis requires data pertaining to oil prices, stock returns and macroeconomic variables. We collect monthly price data of Brent crude oil from U.S. Energy Information Administration Website. The data for macroeconomic variables are collected from CEIC database. ${ }^{7}$ The stock data for companies listed in Shanghai and Shenzhen stock exchanges is collected from DataStream International. Following previous literature (e.g., Jacobs, 2016,

\footnotetext{
${ }^{5}$ Our results remain unchanged if we construct the mispricing score based on at least three valid anomaly ranks as in Lu et al. (2017).

${ }^{6}$ We construct Fama-French monthly factors and provide the details in appendix A2.

${ }^{7}$ The macroeconomic variables are growth of industrial production (IP), growth of money supply (MS2), 30-day inter-bank offer rate, foreign exchange rate (RMB/USD) and recession indicator.
} 
Chui, Titman and Wei, 2010), we restrict our data to A-shares since A-shares account for 99.5\% of total market capitalization; whereas, B-shares are small and illiquid stocks. The sample period is from May 1996 to December 2017, the largest period for which a credible set of data could be obtained.

Following the literature (e.g., Ince and Porter, 2006, Karolyi, Lee and Van Dijk, 2012, Lee, 2011), we apply several screens to clean our data. The detailed screening process is provided in Appendix B.

\section{Baseline Results}

\subsection{Anomaly Returns}

First, we examine baseline mispricing results for each of the 12 anomalies and also for the mispricing score based on those 12 anomalies. Table 1 reports average monthly EW and VW returns and associated Newey-West adjusted $t$-statistics of long, short, long-short, and Fama-French three factors adjusted (alpha) long-short returns.

Panel A of Table 1 reports EW returns. 10 out of 12 anomalies produce positive longshort returns with six statistically significant at least at $10 \%$ level. However, the alphas of nine anomalies are positive with seven statistically significant. The long-short return and alpha of most of these anomalies are consistent with the literature. For example, alpha of net stock issues, composite equity, net operating assets, gross profitability, asset growth, and return on assets is consistent with Jacobs (2016). ${ }^{8}$ The long-short return of the momentum strategy is similar to the ones reported in Chui et al. (2010) and Cheema and Nartea (2017).

\footnotetext{
${ }^{8}$ Jacobs (2016) provides only risk-adjusted (alpha) returns of these anomalies in the online Appendix of his paper.
} 
The long-short return of maximum daily return (MAX) anomaly and idiosyncratic risk (IV) anomaly is consistent with Wan (2018). We find stronger evidence of mispricing once we rank stocks based on mispricing score. For example, we find a long-short return (alpha) at $0.75 \%(0.98 \%)$ per month for mispricing score which is statistically significant at $1 \%$ level.

\section{Table 1 about here}

Panel B of Table 1 shows VW returns. VW returns provide economically significant magnitudes since it gives higher weight to the large equities that are more liquid and have lower transaction costs. Furthermore, VW returns also alleviate the concern that anomalous returns of EW portfolios are due to the impact of small size stocks. The VW returns show that three (six) anomalies produce significant long-short returns (alpha). However, we still find strong evidence of mispricing based on mispricing score. The long-short return (alpha) of mispricing score is $0.52 \%(1.03 \%)$ per month and statistically significant at $10 \%(1 \%)$ level. Overall, the results in Table 1 confirms the presence of anomalous returns in the Chinese market; however, it appears to be relatively weaker than the anomalous returns reported in the literature for the U.S. market (e.g., Stambaugh et al., 2012, Jacobs, 2016). The weaker evidence of anomalous returns is considered as an indication of an efficient market; however, Chen et al. (2010) suggest that it is due to the long-lasting market inefficiency in China instead of the efficient market. They further argue that the persistent mispricing produces weaker anomalous returns in China since anomalous returns result from subsequent price correction; whereas, the Chinese market is seldom corrected.

\section{2. $\quad$ Additional Mispricing Scores}

In the previous section, we constructed a mispricing score based on the availability of at least six non-missing anomalies. As an additional test, we construct a mispricing score based on the availability of 7 to 12 non-missing anomalies and report results in Table 2 . 


\section{Table 2 about here}

We find significant EW long-short returns at $0.69 \%, 0.64 \%, 0.65 \%, 0.67 \%, 0.64 \%$, $0.62 \%$ per month for a mispricing score constructed with the availability of at least $7,8,9$, 10, 11 and 12 anomalies, respectively. The respective EW alphas are also large and statistically significant. The VW returns for mispricing score constructed with the availability of at least 7 to 12 anomalies are also positive but statistically significant when constructed with the availability of at least 9 to 12 anomalies. However, all the VW alphas are large and statistically significant. In sum, these results confirm the presence of mispricing in Chinese stocks irrespective of the number of non-missing anomalies used to construct the mispricing score.

\section{3. $\quad$ Alternative Mispricing Scores}

In the previous sections, we included both IV and low volatility anomalies to construct a mispricing score. The IV anomaly focuses on unsystematic risk whereas low volatility is based on the total risk that includes both systematic and unsystematic risk. To alleviate the concern that inclusion of both IV and low volatility anomalies to construct mispricing score might enhance anomalous returns since both anomalies include unsystematic risk, we construct the mispricing score with the exclusion of low volatility anomaly. ${ }^{9}$

Panel A of Table 3 reports the results of a mispricing score based on 11 anomalies with the availability of at least five non-missing anomalies to construct the mispricing score. We find large and significant EW and VW long-short return and respective alphas that are similar to EW and VW long-short returns and alphas of mispricing score based on 12 anomalies reported in Table 1.

\footnotetext{
${ }^{9}$ We find similar results with the exclusion of IV anomaly instead of low volatility anomaly. For the sake of brevity, we do not report those results.
} 


\section{Table 3 about here}

Recall from Section 2.2 that we apply several screens to clean our data following the suggestions in the literature, and provide the details in Appendix B. One of the screens is the exclusion of stocks with the market capitalization below the 20th percentile at the portfolio formation date. The purpose of this screen is to reduce the impact of small size stocks on our sample. Cheema and Nartea (2014) find that the momentum anomaly is absent in small size stocks in China; whereas they find significant momentum returns for medium and large size stocks. Therefore, in this section we construct the mispricing score based on all the stocks to mitigate the concern that our results might be biased due to the exclusion of small size stocks where anomalous returns might be weaker than medium and large size stocks; hence, the inclusion of small size stocks might lower anomalous returns in China.

Panel B of Table 3 shows the EW and VW returns of mispricing score for all the stocks based on 12 anomalies with at least the availability of six non-missing anomalies to construct the mispricing score. We find EW long-short returns of $1.03 \%$ per month $(t$-stat $=$ $6.27)$ that is larger than the $0.75 \%((t$-stat $=4.55)$ long-short return of mispricing score reported in Table 1. The EW alpha of mispricing score at $1.23 \%$ per month $(t$-stat $=7.39)$ is also larger than then EW alpha at $0.98 \%(t$-stat $=6.36)$ reported in Table 1 . The VW longshort returns and alpha of mispricing score are also similar to the VW long-short returns and alpha reported in Table 1. Overall, our results show that the anomalous returns/mispricing in China is present both in small and large size stocks.

\section{Impact of Oil Returns on Anomalies}

\subsection{Oil states and Anomalies}

Recall from Section 3; our baseline results show the presence of anomalous returns/mispricing in China. However, anomalous returns appear to be relatively weaker than 
the anomalous returns reported for the U.S. market. Chen et al. (2010) suggest that the longlasting market inefficiency in China produces weaker anomalous returns since anomalous returns result from subsequent price correction; whereas, the Chinese market is seldom corrected. Therefore, we expect significant anomalous returns in China when the market is corrected. We hypothesize that Chinese market is corrected following rising oil prices since investors might associate an increase in oil prices with a boost in the economy. Consequently, an increase in oil prices would result in overpricing that would be subsequently corrected when the fundamentals are revealed. Therefore, to the extent, overpricing is the primary form of mispricing, we expect higher anomalous returns (long-short return) following an increase in oil prices (UP oil state) rather than following a decrease in oil prices (DN oil state).

At the beginning of each month $t$, we classify oil state as UP (DN) where Brent crude oil return is positive (negative) over $t-12$ to $t-1$ months. We compute the average monthly returns of 12 anomalies and their mispricing score for UP and DN oil states separately. Table 4 reports VW returns and associated Newey-West adjusted $t$-statistics of long, short, longshort, and Fama-French three factors adjusted (alpha) long-short returns. ${ }^{10}$

\section{Table 4 about here}

Consistent with our hypothesis that the long-short return of anomalies should be stronger following UP than DN oil state, we find that seven (eight) anomalies produce

\footnotetext{
${ }^{10}$ Our results remain similar when we use EW returns. For the sake of brevity, we do not report those results.
} 
positive and statistically significant long-short returns (alpha) following UP oil state. ${ }^{11}$ In contrast, except IV anomaly, all other anomalies produce insignificant long-short returns following DN oil state. Most importantly, the long-short return of mispricing score is positive and significant only following UP oil state. For example, the long-short return of mispricing score is $1.01 \%(-0.15 \%)$ per month following UP (DN) oil state. Furthermore, the difference in the long-short return of mispricing score between UP and DN oil state at $1.15 \%$ per month is statistically significant. In general, the results in Table 4 are consistent with our hypothesis that anomalies are stronger following rising oil prices than falling oil prices.

\section{2. $\quad$ Oil State as a Continuous Variable and Anomalies}

In this section, we examine the relation between the lagged oil returns and the longshort return of anomalies. More specifically, we are interested whether long-short returns increases monotonically with the lagged market returns or not, instead of just examing longshort returns based on binary UP and DN oil state as in Section 4.1.

\section{Table 5 about here}

To examine the monotonic relation between the lagged oil returns and long-short return, we regress long-short returns of each anomaly and the mispricing score on lagged 12month oil returns and the square of lagged 12-month oil returns. We regress on the square of lagged 12-month oil returns to examine the non-linearity between the lagged oil returns and

\footnotetext{
${ }^{11}$ Chen, Cheng and Demirer (2017) report significant industry momentum profits (losses) following UP (DN) oil state. We also find significant momentum profits (losses) following UP (DN) oil state. However, Chen et al. (2017) form momentum portfolios based on industry returns whereas we form traditional momentum portfolios, i.e., based on stock returns.
} 
long-short return. Our results in Table 5 show that the long-short return of ten anomalies is positively related to lagged oil returns, with the long-short return of seven anomalies statistically significant at least at 5\% level. Most importantly, we find that the slope of mispricing score on lagged oil returns is $2.95(t$-stat $=2.42)$ which indicates that one standard deviation increase in lagged oil returns is associated with $2.95 \%$ per month of additional long-short returns. These results confirm our findings in Table 4 that long-short return of anomalies is high (low) when lagged oil returns are high (low). Furthermore, the coefficient of the square of lagged oil returns is insignificant for ten anomalies and also for mispricing score based on all the anomalies, indicating a linear relationship between long-short returns and lagged oil returns.

\section{Table 6 about here}

As an additional test, we allocate long-short returns into terciles based on the 12-

month lagged oil returns and report the results in Table 6 . We expect larger long-short returns for the high lagged oil return tercile if there is a linear relationship between long-short returns and lagged oil returns. Consistent with our expectations, we find positive and significant long-short returns for six anomalies for the high oil tercile whereas only the IV (momentum) anomaly has positive and significant long-short returns for the low (medium IV) oil tercile. Most importantly, we find large and significant long-short returns for the mispricing score at $1.41 \%$ per month $(t$-stat $=3.17)$ for the high oil tercile whereas long-short returns for the low and medium oil tercile are insignificant. These results confirm our results in Table 4 and 
show that long-short returns of anomalies are stronger following UP oil state. Overall, the results in Tables 5 and 6 provide strong support for our hypothesis that anomalies are stronger following rising oil prices than falling oil prices.

\section{Robustness Tests: Alternative Definitions of Oil states and Mispricing Score}

Until now, we define oil state based on lagged 12-month oil returns. In this section, we examine whether our results remain robust once we use alternative definitions of the oil state. $^{12}$

Panel A of Table 7 reports the VW returns based on the lagged 6-month oil state. We find that that the long-short return and alpha of the mispricing score is large and significant following UP oil state, whereas insignificant following DN oil state. Furthermore, the difference in long-short return between UP and DN oil state is large and statistically significant.

\section{Table 7 about here}

Panel B of Table 7 reports the VW returns based on the lagged 24-month oil state. We find large and significant long-short return following UP oil state and insignificant long-short return following DN oil state. However, alphas are statistically significant following both UP and DN oil state. On balance, results in Panels A and B show that long-short return is large and significant only following UP oil state. However, we find that that the oil state based on recent oil returns (lagged 6- and 12-month) better explains mispricing in China. It could be due to the fact that investor's expectations are driven more by recent returns than distant ones (e.g. Greenwood and Shleifer, 2014).

\footnotetext{
${ }^{12}$ For robustness tests, we only focus on the mispricing score.
} 
The investors might associate increase in oil prices (high oil returns) with a boost in the economy. Therefore, we remove the macroeconomic related variation from oil returns by regressing oil returns on five macroeconomic variables, the growth of industrial production (IP), growth of money supply (MS2), 30-day inter-bank offer rate, recession indicator and foreign exchange rate (RMB/USD). Consequently, if the anomalous returns are due to behavioral biases, i.e., investor's optimism, then we expect large and significant long-short return only following UP oil state based on orthogonalized oil returns.

Panel C of Table 7 reports the VW returns based on the lagged 12-month orthogonalized oil state. We find large and significant long-short return following UP oil state, whereas an insignificant long-short return following DN oil state. However, alphas are statistically significant following both UP and DN oil state. Most importantly, we find that the difference in long-short return between UP and DN oil state is positive and significant, indicating that long-short return following UP oil state is significantly higher than following DN oil state. These results provide further support to our hypothesis that anomalous returns are related to overpricing due to increase in oil prices, and macroeconomic variables cannot explain anomalous returns in China.

As an additional test, we construct a mispricing score based on 11 anomalies (with the exclusion of low volatility anomaly) with the availability of at least five non-missing anomaly variables. ${ }^{13}$ Panel D of Table 7 reports the VW returns based on the lagged 12month oil state. Similar to our results in Table 4, we find large and significant long-short return of mispricing score following UP oil state, whereas insignificant long-short return following DN oil state. Furthermore, the difference in long-short return between UP and DN oil state is significant at $1.19 \%$ per month. Overall, the robustness results are consistent with

\footnotetext{
${ }^{13}$ Please refer to the discussion in Section 3.2 on page 10 regarding exclusion of low volatility anomaly from the construction of mispricing score.
} 
our hypothesis that anomalous returns are stronger following rising oil prices than falling oil prices.

\section{Conclusion}

In this paper, we answer two questions: (1) do stock market anomalies exist in China?

(2) Is there any relationship between oil prices and stock market anomalies? Regarding question (1), we find weak evidence of anomalies in China that is consistent with the literature (e.g. Jacobs, 2016, Chen et al., 2010). However, we find strong evidence of mispricing once we construct a mispricing score based on the composite score of all the anomalies used in our paper. This provides support from the largest emerging market to the growing literature that shows that mispricing scores provides stronger evidence of mispricing than single anomalies. Regarding question (2), we find that the stock market anomalies are stronger following rising oil prices than falling oil prices. The findings with regard to question (2) provide strong support for the suggestion that rising oil prices are interpreted as a positive signal by investors, and, hence result in overpricing.

Our study has a few limitations. First, we do not provide complete explanations for each of the anomalies examined in our paper since our aim is to explore the possibility that oil prices play an important role in mispricing that results in higher anomalous returns. Therefore, we leave it to future research to explain the individual anomalies in detail in China. Second, we suggest caution in generalizing our findings to the other markets since the relationship between oil prices and stock market anomalies depend on investors' interpretation of the impact of the changes in oil prices on the economy. However, we suggest that investors interpret the increase in oil prices as a positive signal in expanding economies such as China. 


\section{References}

Ang, A., R. J. Hodrick, Y. Xing and X. Zhang (2006), 'The cross-section of volatility and expected returns', The Journal of Finance, 61, 259-99.

Apergis, N. and S. M. Miller (2009), 'Do structural oil-market shocks affect stock prices?', Energy Economics, 31, 569-75.

Baker, M., B. Bradley and J. Wurgler (2011), 'Benchmarks as limits to arbitrage: Understanding the low-volatility anomaly', Financial Analysts Journal, 67, 40-54.

Bali, T. G., N. Cakici and R. F. Whitelaw (2011), 'Maxing out: Stocks as lotteries and the cross-section of expected returns', Journal of Financial Economics, 99, 427-46.

Basher, S. A., A. A. Haug and P. Sadorsky (2012), 'Oil prices, exchange rates and emerging stock markets', Energy Economics, 34, 227-40.

Basher, S. A. and P. Sadorsky (2006), 'Oil price risk and emerging stock markets', Global finance journal, 17, 224-51.

Blitz, D. C. and P. Van Vliet (2007), 'The Volatility Effect', The Journal of Portfolio Management, 34, 102-13.

Cheema, M. A. and G. V. Nartea (2014), 'Momentum returns and information uncertainty: Evidence from China', Pacific-Basin Finance Journal, 30, 173-88.

Cheema, M. A. and G. V. Nartea (2017), 'Momentum returns, market states, and market dynamics: Is China different?', International Review of Economics \& Finance, 50, 8597.

Chen, C.-D., C.-M. Cheng and R. Demirer (2017), 'Oil and stock market momentum', Energy Economics, 68, 151-59.

Chen, S.-S. (2010), 'Do higher oil prices push the stock market into bear territory?', Energy Economics, 32, 490-95.

Chen, X., K. A. Kim, T. Yao and T. Yu (2010), 'On the predictability of Chinese stock returns', Pacific-Basin Finance Journal, 18, 403-25.

Chui, A. C., S. Titman and K. J. Wei (2010), 'Individualism and momentum around the world', The Journal of Finance, 65, 361-92.

Cong, R.-G., Y.-M. Wei, J.-L. Jiao and Y. Fan (2008), 'Relationships between oil price shocks and stock market: An empirical analysis from China', Energy Policy, 36, 354453.

Cooper, M. J., H. Gulen and M. J. Schill (2008), 'Asset growth and the cross-section of stock returns', The Journal of Finance, 63, 1609-51.

Daniel, K. and S. Titman (2006), 'Market reactions to tangible and intangible information', The Journal of Finance, 61, 1605-43.

Datta, D. D. and R. J. Vigfusson (2017), 'Forecasting China's Role in World Oil Demand', FRBSF Economic Letter.

Dechow, P. M., R. G. Sloan and A. P. Sweeney (1995), 'Detecting earnings management', Accounting review, 193-225.

Driesprong, G., B. Jacobsen and B. Maat (2008), 'Striking oil: another puzzle?', Journal of Financial Economics, 89, 307-27.

Fama, E. F. and K. R. French (1993), 'Common risk factors in the returns on stocks and bonds', Journal of Financial Economics, 33, 3-56.

Fama, E. F. and K. R. French (2006), 'Profitability, investment and average returns', Journal of Financial Economics, 82, 491-518.

Fama, E. F. and K. R. French (2008), 'Dissecting anomalies', The Journal of Finance, 63, 1653-78. 
Fama, E. F. and K. R. French (2012), 'Size, value, and momentum in international stock returns', Journal of Financial Economics, 105, 457-72.

Filis, G. (2010), 'Macro economy, stock market and oil prices: Do meaningful relationships exist among their cyclical fluctuations?', Energy Economics, 32, 877-86.

Gjerde, Ø. and F. Saettem (1999), 'Causal relations among stock returns and macroeconomic variables in a small, open economy', Journal of International Financial Markets, Institutions and Money, 9, 61-74.

Greenwood, R. and A. Shleifer (2014), 'Expectations of returns and expected returns', The Review of Financial Studies, 27, 714-46.

Griffin, J. M., P. J. Kelly and F. Nardari (2010), 'Do market efficiency measures yield correct inferences? A comparison of developed and emerging markets', The Review of Financial Studies, 23, 3225-77.

Hamilton, J. D. (2009), 'Causes and Consequences of the Oil Shock of 2007-08', Brookings Papers on Economic Activity.

Hirshleifer, D., K. Hou, S. H. Teoh and Y. Zhang (2004), 'Do investors overvalue firms with bloated balance sheets?', Journal of Accounting and Economics, 38, 297-331.

Hou, K., G. A. Karolyi and B.-C. Kho (2011), 'What factors drive global stock returns?', The Review of Financial Studies, 24, 2527-74.

Huang, R. D., R. W. Masulis and H. R. Stoll (1996), 'Energy shocks and financial markets', Journal of Futures Markets, 16, 1-27.

Ince, O. S. and R. B. Porter (2006), 'Individual equity return data from Thomson Datastream: Handle with care!', Journal of Financial Research, 29, 463-79.

Jacobs, H. (2016), 'Market maturity and mispricing', Journal of Financial Economics, 122, 270-87.

Jegadeesh, N. and S. Titman (1993), 'Returns to buying winners and selling losers: Implications for stock market efficiency', The Journal of Finance, 48, 65-91.

Jones, C. M. and G. Kaul (1996), 'Oil and the stock markets', The Journal of Finance, 51, 463-91.

Karolyi, G. A., K.-H. Lee and M. A. Van Dijk (2012), 'Understanding commonality in liquidity around the world', Journal of Financial Economics, 105, 82-112.

Kilian, L. and C. Park (2009), 'The impact of oil price shocks on the US stock market', International Economic Review, 50, 1267-87.

Kling, J. L. (1985), 'Oil price shocks and stock market behavior', The Journal of Portfolio Management, 12, 34-39.

Kollias, C., C. Kyrtsou and S. Papadamou (2013), 'The effects of terrorism and war on the oil price-stock index relationship', Energy Economics, 40, 743-52.

Lee, K.-H. (2011), 'The world price of liquidity risk', Journal of Financial Economics, 99, 136-61.

Leung, G. C. (2011), 'China's energy security: Perception and reality', Energy Policy, 39, 1330-37.

Li, S.-F., H.-M. Zhu and K. Yu (2012), 'Oil prices and stock market in China: A sector analysis using panel cointegration with multiple breaks', Energy Economics, 34, 1951-58.

Loughran, T. and J. R. Ritter (1995), 'The new issues puzzle', The Journal of Finance, 50, 23 51.

Lu, X., R. F. Stambaugh and Y. Yuan (2017), 'Anomalies Abroad: Beyond Data Mining'.

Miller, E. M. (1977), 'Risk, uncertainty, and divergence of opinion', The Journal of Finance, 32, 1151-68.

Miller, J. I. and R. A. Ratti (2009), 'Crude oil and stock markets: Stability, instability, and bubbles', Energy Economics, 31, 559-68. 
Narayan, P. K. and S. Narayan (2010), 'Modelling the impact of oil prices on Vietnam's stock prices', Applied Energy, 87, 356-61.

Novy-Marx, R. (2013), 'The other side of value: The gross profitability premium', Journal of Financial Economics, 108, 1-28.

Papapetrou, E. (2001), 'Oil price shocks, stock market, economic activity and employment in Greece', Energy Economics, 23, 511-32.

Park, J. and R. A. Ratti (2008), 'Oil price shocks and stock markets in the US and 13 European countries', Energy Economics, 30, 2587-608.

Pontiff, J. and A. Woodgate (2008), 'Share issuance and cross-sectional returns', The Journal of Finance, 63, 921-45.

Ritter, J. R. (1991), 'The long-run performance of initial public offerings', The Journal of Finance, 46, 3-27.

Sadorsky, P. (1999), 'Oil price shocks and stock market activity', Energy Economics, 21, 44969.

Silvapulle, P., R. Smyth, X. Zhang and J.-P. Fenech (2017), 'Nonparametric panel data model for crude oil and stock market prices in net oil importing countries', Energy Economics, 67, 255-67.

Sloan, A. (1996), 'Do Stock Prices Fully Reflect Information in Accruals and Cash Flows about Future Earnings? ', Accounting review, 71, 289-315.

Smyth, R. and P. K. Narayan (2018), 'What do we know about oil prices and stock returns?', International Review of Financial Analysis, 57, 148-56.

Stambaugh, R. F., J. Yu and Y. Yuan (2012), 'The short of it: Investor sentiment and anomalies', Journal of Financial Economics, 104, 288-302.

Stambaugh, R. F., J. Yu and Y. Yuan (2014), 'The long of it: Odds that investor sentiment spuriously predicts anomaly returns', Journal of Financial Economics, 114, 613-19.

Stambaugh, R. F., J. Yu and Y. Yuan (2015), 'Arbitrage asymmetry and the idiosyncratic volatility puzzle', The Journal of Finance, 70, 1903-48.

Titman, S., K. J. Wei and F. Xie (2004), 'Capital investments and stock returns', Journal of Financial and Quantitative Analysis, 39, 677-700.

Wan, X. (2018), 'Is the idiosyncratic volatility anomaly driven by the MAX or MIN effect? Evidence from the Chinese stock market', International Review of Economics \& Finance, 53, 1-15.

Xing, Y. (2007), 'Interpreting the value effect through the Q-theory: An empirical investigation', The Review of Financial Studies, 21, 1767-95.

You, W., Y. Guo, H. Zhu and Y. Tang (2017), 'Oil price shocks, economic policy uncertainty and industry stock returns in China: Asymmetric effects with quantile regression', Energy Economics, 68, 1-18.

Zhang, C. and X. Chen (2011), 'The impact of global oil price shocks on China's stock returns: Evidence from the ARJI (-ht)-EGARCH model', Energy, 36, 6627-33.

Zhu, H.-M., R. Li and S. Li (2014), 'Modelling dynamic dependence between crude oil prices and Asia-Pacific stock market returns', International Review of Economics \& Finance, 29, 208-23.

Zhu, H.-M., S.-F. Li and K. Yu (2011), 'Crude oil shocks and stock markets: A panel threshold cointegration approach', Energy Economics, 33, 987-94.

Zhu, H., Y. Guo, W. You and Y. Xu (2016), 'The heterogeneity dependence between crude oil price changes and industry stock market returns in China: Evidence from a quantile regression approach', Energy Economics, 55, 30-41. 


\section{Table 1: Anomaly Returns}

This table reports the equally weighted and value weighted returns for all the 12 anomalies and mispricing score based on the combination of these anomalies (where at least six valid anomaly variables are available). The long, short, long-short and long-short alpha returns are reported in percentage, and robust Newey-West adjusted $t$-statistics are provided in parentheses. The sample period is from May 1996 to December 2017.

\begin{tabular}{|c|c|c|c|c|c|c|c|c|}
\hline \multicolumn{5}{|c|}{ Equally weighted returns (\%) } & \multicolumn{4}{|c|}{ Value weighted returns (\%) } \\
\hline Anomaly & Long (A) & Short (B) & A-B & Alpha & Long & Short & A-B & Alpha \\
\hline Net stock issues & $\begin{array}{c}1.12 \\
(1.87)\end{array}$ & $\begin{array}{c}1.21 \\
(1.97)\end{array}$ & $\begin{array}{c}-0.08 \\
(-0.58)\end{array}$ & $\begin{array}{c}-0.21 \\
(-1.72)\end{array}$ & $\begin{array}{c}0.75 \\
(1.46)\end{array}$ & $\begin{array}{c}0.83 \\
(1.46)\end{array}$ & $\begin{array}{c}-0.08 \\
(-0.38)\end{array}$ & $\begin{array}{c}-0.02 \\
(-0.07)\end{array}$ \\
\hline $\begin{array}{l}\text { Composite } \\
\text { equity }\end{array}$ & $\begin{array}{c}1.30 \\
(2.33)\end{array}$ & $\begin{array}{c}1.04 \\
(1.72)\end{array}$ & $\begin{array}{c}0.26 \\
(2.01)\end{array}$ & $\begin{array}{c}0.56 \\
(5.30)\end{array}$ & $\begin{array}{c}0.84 \\
(1.69)\end{array}$ & $\begin{array}{c}0.64 \\
(1.17)\end{array}$ & $\begin{array}{c}0.20 \\
(0.86)\end{array}$ & $\begin{array}{c}0.66 \\
(3.25)\end{array}$ \\
\hline Momentum & $\begin{array}{c}1.08 \\
(1.81)\end{array}$ & $\begin{array}{c}0.99 \\
(1.57)\end{array}$ & $\begin{array}{c}0.09 \\
(0.32)\end{array}$ & $\begin{array}{c}0.50 \\
(1.81)\end{array}$ & $\begin{array}{c}0.75 \\
(1.42)\end{array}$ & $\begin{array}{c}0.70 \\
(1.18)\end{array}$ & $\begin{array}{c}0.05 \\
(0.14)\end{array}$ & $\begin{array}{c}0.47 \\
(1.15)\end{array}$ \\
\hline Accruals & $\begin{array}{c}1.04 \\
(1.71)\end{array}$ & $\begin{array}{c}0.94 \\
(1.53)\end{array}$ & $\begin{array}{c}0.10 \\
(0.63)\end{array}$ & $\begin{array}{c}0.11 \\
(0.89)\end{array}$ & $\begin{array}{c}0.59 \\
(1.10)\end{array}$ & $\begin{array}{c}0.58 \\
(1.02)\end{array}$ & $\begin{array}{c}0.01 \\
(0.02)\end{array}$ & $\begin{array}{c}0.30 \\
(1.49)\end{array}$ \\
\hline $\begin{array}{l}\text { Net operating } \\
\text { assets }\end{array}$ & $\begin{array}{c}1.21 \\
(2.02)\end{array}$ & $\begin{array}{c}0.95 \\
(1.59)\end{array}$ & $\begin{array}{c}0.25 \\
(2.27)\end{array}$ & $\begin{array}{c}0.31 \\
(2.52)\end{array}$ & $\begin{array}{c}0.60 \\
(1.16)\end{array}$ & $\begin{array}{c}0.52 \\
(0.95)\end{array}$ & $\begin{array}{c}0.08 \\
(0.27)\end{array}$ & $\begin{array}{c}0.78 \\
(2.74)\end{array}$ \\
\hline $\begin{array}{l}\text { Gross } \\
\text { profitability }\end{array}$ & $\begin{array}{c}1.13 \\
(1.99)\end{array}$ & $\begin{array}{c}1.02 \\
(1.60)\end{array}$ & $\begin{array}{c}0.10 \\
(0.40)\end{array}$ & $\begin{array}{c}0.58 \\
(2.99)\end{array}$ & $\begin{array}{c}0.76 \\
(1.49)\end{array}$ & $\begin{array}{c}0.69 \\
(1.17)\end{array}$ & $\begin{array}{c}0.07 \\
(0.20)\end{array}$ & $\begin{array}{c}0.75 \\
(2.94)\end{array}$ \\
\hline Asset growth & $\begin{array}{c}1.12 \\
(1.78)\end{array}$ & $\begin{array}{c}0.93 \\
(1.56)\end{array}$ & $\begin{array}{c}0.19 \\
(0.82)\end{array}$ & $\begin{array}{c}-0.18 \\
(-1.08)\end{array}$ & $\begin{array}{c}0.71 \\
(1.20)\end{array}$ & $\begin{array}{c}0.52 \\
(0.94)\end{array}$ & $\begin{array}{c}0.19 \\
(0.58)\end{array}$ & $\begin{array}{c}-0.47 \\
(-1.74)\end{array}$ \\
\hline $\begin{array}{l}\text { Return on } \\
\text { assets }\end{array}$ & $\begin{array}{c}1.04 \\
(1.81)\end{array}$ & $\begin{array}{c}1.10 \\
(1.72)\end{array}$ & $\begin{array}{l}-0.06 \\
(-0.22)\end{array}$ & $\begin{array}{c}0.16 \\
(0.73)\end{array}$ & $\begin{array}{c}0.72 \\
(1.39)\end{array}$ & $\begin{array}{c}0.69 \\
(1.31)\end{array}$ & $\begin{array}{c}0.04 \\
(0.10)\end{array}$ & $\begin{array}{c}-0.06 \\
(-0.16)\end{array}$ \\
\hline $\begin{array}{l}\text { Investment-to- } \\
\text { assets }\end{array}$ & $\begin{array}{c}1.53 \\
(2.29)\end{array}$ & $\begin{array}{c}1.19 \\
(1.90)\end{array}$ & $\begin{array}{c}0.34 \\
(1.83)\end{array}$ & $\begin{array}{c}-0.01 \\
(-0.07)\end{array}$ & $\begin{array}{c}0.81 \\
(1.38)\end{array}$ & $\begin{array}{c}0.54 \\
(1.02)\end{array}$ & $\begin{array}{c}0.27 \\
(0.96)\end{array}$ & $\begin{array}{c}-0.28 \\
(-1.06)\end{array}$ \\
\hline $\begin{array}{l}\text { Maximum daily } \\
\text { return }\end{array}$ & $\begin{array}{c}1.40 \\
(2.39)\end{array}$ & $\begin{array}{c}0.50 \\
(0.78)\end{array}$ & $\begin{array}{c}0.90 \\
(4.10)\end{array}$ & $\begin{array}{c}1.07 \\
(4.65)\end{array}$ & $\begin{array}{c}0.89 \\
(1.80)\end{array}$ & $\begin{array}{c}0.27 \\
(0.45)\end{array}$ & $\begin{array}{c}0.62 \\
(1.85)\end{array}$ & $\begin{array}{c}1.03 \\
(2.65)\end{array}$ \\
\hline $\begin{array}{l}\text { Idiosyncratic } \\
\text { risk }\end{array}$ & $\begin{array}{c}1.63 \\
(2.66)\end{array}$ & $\begin{array}{c}0.94 \\
(1.41)\end{array}$ & $\begin{array}{c}0.69 \\
(3.20)\end{array}$ & $\begin{array}{c}0.59 \\
(3.20)\end{array}$ & $\begin{array}{c}1.31 \\
(2.31)\end{array}$ & $\begin{array}{c}0.46 \\
(0.76)\end{array}$ & $\begin{array}{c}0.85 \\
(2.69)\end{array}$ & $\begin{array}{c}0.49 \\
(1.67)\end{array}$ \\
\hline Low volatility & $\begin{array}{c}1.34 \\
(2.52)\end{array}$ & $\begin{array}{c}0.81 \\
(1.20)\end{array}$ & $\begin{array}{c}0.54 \\
(2.36)\end{array}$ & $\begin{array}{c}0.86 \\
(3.88)\end{array}$ & $\begin{array}{c}1.00 \\
(2.09)\end{array}$ & $\begin{array}{c}0.31 \\
(0.48)\end{array}$ & $\begin{array}{c}0.70 \\
(2.21)\end{array}$ & $\begin{array}{c}1.26 \\
(3.73)\end{array}$ \\
\hline $\begin{array}{l}\text { Mispricing } \\
\text { score }\end{array}$ & $\begin{array}{c}1.50 \\
(2.73)\end{array}$ & $\begin{array}{c}0.75 \\
(1.16)\end{array}$ & $\begin{array}{c}0.75 \\
(4.55)\end{array}$ & $\begin{array}{c}0.98 \\
(6.36)\end{array}$ & $\begin{array}{c}0.92 \\
(2.01)\end{array}$ & $\begin{array}{c}0.41 \\
(0.68)\end{array}$ & $\begin{array}{c}0.52 \\
(1.74)\end{array}$ & $\begin{array}{c}1.03 \\
(3.97)\end{array}$ \\
\hline
\end{tabular}




\section{Table 2: Alternative Definitions of Mispricing Scores}

This table reports the equally weighted and value weighted returns for the mispricing score based on the combination of stocks where at least seven, eight, nine, ten, 11, and all 12 valid anomaly variables are available to construct the mispricing score. The long, short, long-short and Long-short alpha returns are reported in percentage, and robust Newey-West adjusted $t$-statistics are provided in parentheses. The sample period is from May 1996 to December 2017.

\begin{tabular}{lcccc|cccc}
\hline \multicolumn{5}{c}{ Equally weighted returns (\%) } & \multicolumn{4}{c}{ Value weighted returns (\%) } \\
\hline Mispricing & Long (A) & Short (B) & A-B & Alpha & Long & Short & A-B & Alpha \\
\hline \multirow{2}{*}{7 anomalies } & 1.46 & 0.78 & 0.69 & 0.94 & 0.89 & 0.45 & 0.45 & 1.01 \\
& $(2.66)$ & $(1.20)$ & $(3.67)$ & $(5.59)$ & $(1.93)$ & $(0.75)$ & $(1.37)$ & $(3.53)$ \\
& 1.53 & 0.89 & 0.64 & 0.90 & 1.04 & 0.54 & 0.50 & 1.03 \\
anomalies & $(2.76)$ & $(1.37)$ & $(3.33)$ & $(5.27)$ & $(2.20)$ & $(0.91)$ & $(1.52)$ & $(3.77)$ \\
& 1.52 & 0.87 & 0.65 & 0.89 & 1.11 & 0.50 & 0.61 & 1.17 \\
9 anomalies & $(2.75)$ & $(1.34)$ & $(3.41)$ & $(5.40)$ & $(2.36)$ & $(0.84)$ & $(1.90)$ & $(4.28)$ \\
& 1.53 & 0.86 & 0.67 & 0.92 & 1.16 & 0.50 & 0.66 & 1.17 \\
10 anomalies & $(2.77)$ & $(1.32)$ & $(3.52)$ & $(5.66)$ & $(2.43)$ & $(0.82)$ & $(2.14)$ & $(4.41)$ \\
& 1.52 & 0.88 & 0.64 & 1.15 & 1.12 & 0.49 & 0.63 & 1.15 \\
11 anomalies & $(2.76)$ & $(1.34)$ & $(3.11)$ & $(3.96)$ & $(2.32)$ & $(0.81)$ & $(2.05)$ & $(3.96)$ \\
& 1.69 & 1.07 & 0.62 & 0.96 & 1.31 & 0.73 & 0.58 & 1.26 \\
\multirow{4}{*}{ anomalies } & $(3.01)$ & $(1.55)$ & $(2.83)$ & $(5.31)$ & $(2.70)$ & $(1.16)$ & $(1.81)$ & $(4.33)$ \\
& & & & & & & &
\end{tabular}




\section{Table 3: Additional Mispricing Scores}

This table reports the equally weighted and value weighted returns for the additional mispricing scores. Panel A reports the mispricing score based on the combination of all the anomalies except low volatility anomaly where at least five anomaly variables are available to construct the mispricing score. Panel B reports the mispricing score for all stocks (including stocks with market capitalization below 20th percentile) based on the combination of all the anomalies where at least six anomaly variables are available to construct the mispricing score. The long, short, long-short and Long-short alpha returns are reported in percentage, and robust Newey-West adjusted $t$-statistics are provided in parentheses. The sample period is from May 1996 to December 2017.

\begin{tabular}{|c|c|c|c|c|c|c|c|}
\hline \multicolumn{8}{|c|}{ Panel A: Mispricing score based on all anomalies except low volatility anomaly } \\
\hline \multicolumn{4}{|c|}{ Equally weighted returns $(\%)$} & \multicolumn{4}{|c|}{ Value weighted returns $(\%)$} \\
\hline Long (A) & Short (B) & A-B & Alpha & Long & Short & A-B & Alpha \\
\hline 1.51 & 0.80 & 0.71 & 0.92 & 1.08 & 0.51 & 0.57 & 0.97 \\
\hline$(2.67)$ & $(1.26)$ & $(4.75)$ & $(6.58)$ & $(2.22)$ & $(0.86)$ & $(2.11)$ & $(3.85)$ \\
\hline \multicolumn{8}{|c|}{ Panel B: Mispricing score based on all anomalies for all stocks } \\
\hline \multicolumn{4}{|c|}{ Equally weighted returns (\%) } & \multicolumn{4}{|c|}{ Value weighted returns $(\%)$} \\
\hline Long (A) & Short (B) & A-B & Alpha & Long & Short & A-B & Alpha \\
\hline 2.01 & 0.97 & 1.03 & 1.23 & 1.00 & 0.46 & 0.54 & 1.05 \\
\hline$(3.50)$ & $(1.49)$ & $(6.27)$ & (7.39) & $(2.18)$ & $(0.77)$ & $(1.82)$ & $(4.10)$ \\
\hline
\end{tabular}




\section{Table 4: Oil State and Anomaly Returns}

This table reports the value weighted returns for all the 12 anomalies and mispricing score based on the combination of these anomalies (where at least six valid anomaly variables are available) following UP and DOWN oil state. At the beginning of each month $t$, we define UP (DOWN) market state where lagged 12-month Brent crude oil return is non-negative (negative). The long, short, long-short and long-short alpha returns are reported in percentage, and robust Newey-West adjusted $t$-statistics are provided in parentheses. The sample period is from May 1996 to December 2017.

\begin{tabular}{|c|c|c|c|c|c|c|c|c|c|c|}
\hline \multirow[b]{2}{*}{ Anomaly } & \multicolumn{4}{|c|}{ UP } & \multicolumn{4}{|c|}{ DOWN } & \multicolumn{2}{|c|}{ UP-DOWN } \\
\hline & Long (A) & Short (B) & A-B (C) & Alpha & Long (A) & Short (B) & A-B (D) & Alpha & C-D & Alpha \\
\hline \multirow{2}{*}{ Net stock issues } & 0.24 & 0.15 & 0.09 & 0.14 & 1.44 & 1.75 & -0.31 & -0.24 & 0.41 & 0.38 \\
\hline & $(0.38)$ & $(0.21)$ & $(0.44)$ & $(0.66)$ & $(1.70)$ & $(1.90)$ & $(-0.81)$ & $(-0.72)$ & $(0.98)$ & $(1.10)$ \\
\hline \multirow{2}{*}{ Composite equity } & 0.46 & 0.06 & 0.40 & 0.64 & 1.36 & 1.44 & -0.08 & 0.70 & 0.48 & -0.06 \\
\hline & $(0.72)$ & $(0.09)$ & (1.66) & $(3.23)$ & $(1.72)$ & $(1.62)$ & $(-0.21)$ & $(2.01)$ & $(1.00)$ & $(-0.17)$ \\
\hline \multirow{2}{*}{ Momentum } & 0.64 & -0.36 & 0.99 & 1.07 & 0.91 & 2.14 & -1.23 & -0.42 & 2.22 & 1.49 \\
\hline & $(0.93)$ & $(-0.48)$ & $(2.61)$ & $(2.81)$ & (1.09) & $(2.19)$ & $(-1.76)$ & $(-0.59)$ & $(2.94)$ & (1.94) \\
\hline \multirow{2}{*}{ Accruals } & 0.28 & -0.18 & 0.45 & 0.60 & 1.01 & 1.61 & -0.61 & -0.14 & 1.06 & 0.74 \\
\hline & $(0.41)$ & $(-0.25)$ & $(1.58)$ & $(2.11)$ & $(1.17)$ & (1.69) & $(-1.88)$ & $(-0.51)$ & $(2.44)$ & $(1.85)$ \\
\hline \multirow{2}{*}{ Net operating assets } & 0.42 & -0.25 & 0.67 & 0.99 & 0.85 & 1.56 & -0.71 & 0.49 & 1.38 & 0.50 \\
\hline & $(0.62)$ & $(-0.36)$ & $(2.32)$ & $(2.96)$ & $(1.06)$ & $(1.74)$ & $(-1.37)$ & $(1.12)$ & $(2.17)$ & $(1.01)$ \\
\hline \multirow{2}{*}{ Gross profitability } & 0.50 & -0.19 & 0.69 & 0.93 & 1.11 & 1.90 & -0.79 & 0.49 & 1.48 & 0.44 \\
\hline & $(0.75)$ & $(-0.28)$ & $(2.11)$ & $(3.30)$ & $(1.42)$ & $(1.86)$ & $(-1.48)$ & $(1.11)$ & $(2.30)$ & $(0.88)$ \\
\hline \multirow{2}{*}{ Asset growth } & 0.10 & -0.04 & 0.14 & -0.14 & 1.55 & 1.29 & 0.26 & -0.94 & -0.11 & 0.80 \\
\hline & $(0.15)$ & $(-0.05)$ & $(0.33)$ & $(-0.47)$ & $(1.5)$ & $(1.49)$ & $(0.51)$ & $(-2.41)$ & $(-0.17)$ & $(1.79)$ \\
\hline \multirow{2}{*}{ Return on assets } & 0.46 & 0.48 & -0.01 & -0.15 & 1.08 & 0.97 & 0.11 & 0.08 & -0.12 & -0.23 \\
\hline & $(0.71)$ & $(0.69)$ & $(-0.03)$ & $(-0.36)$ & $(1.27)$ & $(1.20)$ & $(0.18)$ & $(0.17)$ & $(-0.15)$ & $(-0.41)$ \\
\hline \multirow{2}{*}{ Investment-to-assets } & 0.03 & 0.01 & 0.02 & -0.22 & 1.87 & 1.26 & 0.61 & -0.35 & -0.59 & 0.13 \\
\hline & $(0.05)$ & $(0.01)$ & $(0.07)$ & $(-0.82)$ & (1.89) & $(1.51)$ & $(1.35)$ & $(-0.74)$ & $(-1.03)$ & $(0.24)$ \\
\hline \multirow{2}{*}{ Maximum daily return } & 0.38 & -0.51 & 0.88 & 1.06 & 1.56 & 1.29 & 0.27 & 0.98 & 0.62 & 0.08 \\
\hline & $(0.59)$ & $(-0.69)$ & $(1.96)$ & $(2.38)$ & $(2.01)$ & $(1.30)$ & $(0.48)$ & $(1.66)$ & $(0.84)$ & $(0.11)$ \\
\hline \multirow{2}{*}{ Idiosyncratic risk } & 0.54 & -0.09 & 0.63 & 0.47 & 2.44 & 1.25 & 1.18 & 0.52 & -0.56 & -0.05 \\
\hline & $(0.78)$ & $(-0.12)$ & $(1.64)$ & $(1.46)$ & $(2.53)$ & $(1.26)$ & $(2.37)$ & $(1.03)$ & $(-0.82)$ & $(-0.08)$ \\
\hline \multirow{2}{*}{ Low volatility } & 0.58 & -0.26 & 0.84 & 1.06 & 1.59 & 1.07 & 0.51 & 1.54 & -0.56 & -0.48 \\
\hline & $(0.94)$ & $(-0.33)$ & $(2.06)$ & $(2.77)$ & $(2.07)$ & $(1.04)$ & $(1.03)$ & $(2.77)$ & $(-0.82)$ & $(-0.74)$ \\
\hline \multirow{2}{*}{ Mispricing score } & 0.62 & -0.39 & 1.01 & 1.19 & 1.34 & 1.49 & -0.15 & 0.80 & 1.15 & 0.39 \\
\hline & $(1.06)$ & $(-0.52)$ & $(3.06)$ & (4.17) & (1.79) & $(1.54)$ & $(-0.30)$ & (1.68) & $(1.90)$ & $(0.71)$ \\
\hline
\end{tabular}




\section{Table 5: Lagged Oil Returns as a Continous Measure of the Oil State}

This table reports the estimates of the monthly regression coefficients

$$
R_{P 1-P 5, t+1}=\alpha+b L A G R O_{t}+c L A G R O_{t}^{2}+\mu_{t+1}
$$

Where $R_{P 1-P 5, t+1}$ is the long-short value weighted return of each anomaly and mispricing score based on the combination of these anomalies (where at least six valid anomaly variables are available). LAGRO is lagged 12month Brent crude oil return, and $L A G R O^{2}$ is the 12-month Brent crude oil return squared. The robust NeweyWest adjusted $t$-statistics are provided in parentheses. The sample period is from May 1996 to December 2017.

\begin{tabular}{|c|c|c|c|c|}
\hline Anomaly & Intercept & $L A G R O$ & $L A G R O^{2}$ & $R^{2}$ \\
\hline Net stock issues & $\begin{array}{c}-0.06 \\
(-0.29)\end{array}$ & $\begin{array}{c}1.38 \\
(2.17)\end{array}$ & $\begin{array}{l}-1.05 \\
(-1.29)\end{array}$ & 1.70 \\
\hline Composite equity & $\begin{array}{c}0.37 \\
(1.51)\end{array}$ & $\begin{array}{c}2.01 \\
(2.29)\end{array}$ & $\begin{array}{c}-2.38 \\
(-2.62)\end{array}$ & 3.20 \\
\hline Momentum & $\begin{array}{c}0.14 \\
(0.32)\end{array}$ & $\begin{array}{c}3.78 \\
(3.26)\end{array}$ & $\begin{array}{c}-3.09 \\
(-1.48)\end{array}$ & 3.80 \\
\hline Accruals & $\begin{array}{c}0.00 \\
(-0.02)\end{array}$ & $\begin{array}{l}1.95 \\
(2.74)\end{array}$ & $\begin{array}{c}-1.27 \\
(-1.41)\end{array}$ & 3.10 \\
\hline Net operating assets & $\begin{array}{c}0.08 \\
(0.24)\end{array}$ & $\begin{array}{c}1.79 \\
(1.97)\end{array}$ & $\begin{array}{l}-1.18 \\
(-1.27)\end{array}$ & 4.20 \\
\hline Gross profitability & $\begin{array}{c}0.06 \\
(0.17)\end{array}$ & $\begin{array}{c}1.15 \\
(1.08)\end{array}$ & $\begin{array}{l}-0.75 \\
(-0.8)\end{array}$ & 0.50 \\
\hline Asset growth & $\begin{array}{c}0.28 \\
(0.69)\end{array}$ & $\begin{array}{c}0.53 \\
(0.80)\end{array}$ & $\begin{array}{c}-0.87 \\
(-0.67)\end{array}$ & 0.20 \\
\hline Return on assets & $\begin{array}{c}0.35 \\
(0.93)\end{array}$ & $\begin{array}{c}-0.35 \\
(-0.37)\end{array}$ & $\begin{array}{c}-1.63 \\
(-1.17)\end{array}$ & 1.10 \\
\hline Investment-to-assets & $\begin{array}{c}0.20 \\
(0.63)\end{array}$ & $\begin{array}{c}-0.45 \\
(-0.49)\end{array}$ & $\begin{array}{c}0.70 \\
(0.68)\end{array}$ & 0.20 \\
\hline Maximum daily return & $\begin{array}{c}0.86 \\
(2.32)\end{array}$ & $\begin{array}{c}2.14 \\
(1.60)\end{array}$ & $\begin{array}{c}-2.80 \\
(-1.88)\end{array}$ & 1.80 \\
\hline Idiosyncratic risk & $\begin{array}{c}1.00 \\
(2.63)\end{array}$ & $\begin{array}{c}0.82 \\
(0.82)\end{array}$ & $\begin{array}{l}-1.38 \\
(-0.77)\end{array}$ & 0.50 \\
\hline Low volatility & $\begin{array}{c}0.86 \\
(2.38)\end{array}$ & $\begin{array}{c}2.59 \\
(2.26)\end{array}$ & $\begin{array}{c}-2.68 \\
(-1.46)\end{array}$ & 2.30 \\
\hline Mispricing score & $\begin{array}{c}0.58 \\
(1.87)\end{array}$ & $\begin{array}{c}2.95 \\
(2.42)\end{array}$ & $\begin{array}{c}-2.38 \\
(-1.50) \\
\end{array}$ & 3.60 \\
\hline
\end{tabular}




\section{Table 6: Anomaly Returns by Terciles of Lagged 12-month Oil Returns}

This table reports the long-short value weighted return returns for all the 12 anomalies and mispricing score based on the combination of these anomalies (where at least six valid anomaly variables are available) allocated into terciles based on the full sample of lagged 12-month Brent crude oil return. The robust Newey-West adjusted $t$-statistics are provided in parentheses. The sample period is from May 1996 to December 2017.

\begin{tabular}{lccc}
\hline Anomaly & Low & 2 & High \\
\hline Net stock issues & -0.29 & -0.11 & 0.16 \\
& $(-0.48)$ & $(-0.37)$ & $(0.58)$ \\
Composite equity & -0.13 & 0.14 & 0.58 \\
& $(-0.24)$ & $(0.43)$ & $(2.06)$ \\
Momentum & -1.77 & 1.31 & 0.60 \\
& $(-2.40)$ & $(2.65)$ & $(1.05)$ \\
Accruals & -0.60 & -0.15 & 0.76 \\
Net operating assets & $(-1.47)$ & $(-0.45)$ & $(2.11)$ \\
& -0.33 & -0.13 & 0.71 \\
Gross profitability & $-0.60)$ & $(-0.19)$ & $(1.94)$ \\
& -1.06 & 0.85 & 0.39 \\
Asset growth & $(-1.86)$ & $(1.55)$ & $(0.87)$ \\
Return on assets & 0.29 & -0.04 & 0.32 \\
Investment-to-assets & $(0.56)$ & $(-0.05)$ & $(0.68)$ \\
Maximum daily return & -0.32 & 0.88 & -0.45 \\
Idiosyncratic risk & $(-0.47)$ & $(1.38)$ & $(-0.81)$ \\
Low volatility & 0.76 & -0.25 & 0.31 \\
Mispricing score & $(1.53)$ & $(-0.54)$ & $(0.61)$ \\
\hline
\end{tabular}


Table 7: Alternative Definitions of Oil State and Mispricing Score

This table reports the value weighted returns of portfolios based on the alternative definitions of oil state. Panel A (B) reports the returns following UP and DN oil state where oil state is defined based on lagged 6- and 24-month, respectively. Panel C reports the returns following UP and DOWN oil state where oil state is defined based on lagged 12-month orthogonalized oil returns. The orthogonalized oil returns are obtained by regressing monthly oil returns on macroeconomic variables. Panel D reports the return for mispricing score based on the combination of all the anomalies except low volatility anomaly following UP and DOWN oil market state based on lagged 12-month oil returns. The long, short, long-short and Long-short alpha returns are reported in percentage, and robust Newey-West adjusted $t$-statistics are provided in parentheses. The sample period is from May 1996 to December 2017.

Panel A: Value weighted returns following lagged 6-month oil returns

\begin{tabular}{|c|c|c|c|c|c|c|c|c|c|}
\hline \multicolumn{4}{|c|}{ UP } & \multicolumn{4}{|c|}{ DOWN } & \multicolumn{2}{|c|}{ UP-DOWN } \\
\hline Long (A) & Short (B) & A-B (C) & Alpha & Long (A) & Short (B) & A-B (D) & Alpha & C-D & Alpha \\
\hline $\begin{array}{c}0.86 \\
(1.36)\end{array}$ & $\begin{array}{c}-0.18 \\
(-0.24)\end{array}$ & $\begin{array}{c}1.05 \\
(3.50)\end{array}$ & $\begin{array}{c}1.35 \\
(4.57)\end{array}$ & $\begin{array}{c}1.00 \\
(1.51)\end{array}$ & $\begin{array}{c}1.18 \\
(1.26)\end{array}$ & $\begin{array}{c}-0.18 \\
(-0.34)\end{array}$ & $\begin{array}{c}0.59 \\
(1.46)\end{array}$ & $\begin{array}{c}1.23 \\
(2.03)\end{array}$ & $\begin{array}{c}0.75 \\
(1.58)\end{array}$ \\
\hline
\end{tabular}

Panel B: Value weighted returns following lagged 24-month oil returns

\begin{tabular}{|c|c|c|c|c|c|c|c|c|c|}
\hline \multicolumn{4}{|c|}{ High } & \multicolumn{4}{|c|}{ Low } & \multicolumn{2}{|c|}{ High-Low } \\
\hline Long (A) & Short (B) & A-B (C) & Alpha & Long (A) & Short (B) & A-B (D) & Alpha & C-D & Alpha \\
\hline $\begin{array}{c}0.49 \\
(0.82)\end{array}$ & $\begin{array}{c}-0.21 \\
(-0.27)\end{array}$ & $\begin{array}{c}0.70 \\
(1.97)\end{array}$ & $\begin{array}{c}0.91 \\
(2.97)\end{array}$ & $\begin{array}{c}1.50 \\
(2.09)\end{array}$ & $\begin{array}{c}1.22 \\
(1.25)\end{array}$ & $\begin{array}{c}0.28 \\
(0.54)\end{array}$ & $\begin{array}{c}1.19 \\
(2.81)\end{array}$ & $\begin{array}{c}0.42 \\
(0.70)\end{array}$ & $\begin{array}{c}-0.29 \\
(-0.56)\end{array}$ \\
\hline
\end{tabular}

Panel C: Value weighted returns following high (low) orthogonalized oil market state

\begin{tabular}{|c|c|c|c|c|c|c|c|c|c|}
\hline \multicolumn{4}{|c|}{ High } & \multicolumn{4}{|c|}{ Low } & \multicolumn{2}{|c|}{ High-Low } \\
\hline Long (A) & Short (B) & A-B (C) & Alpha & Long (A) & Short (B) & A-B (D) & Alpha & C-D & Alpha \\
\hline $\begin{array}{c}-0.14 \\
(-0.22)\end{array}$ & $\begin{array}{c}-1.24 \\
(-1.46)\end{array}$ & $\begin{array}{c}1.10 \\
(2.94)\end{array}$ & $\begin{array}{c}1.38 \\
(4.09)\end{array}$ & $\begin{array}{c}1.72 \\
(2.71)\end{array}$ & $\begin{array}{c}1.64 \\
(2.00)\end{array}$ & $\begin{array}{c}0.08 \\
(0.19)\end{array}$ & $\begin{array}{c}0.76 \\
(2.26)\end{array}$ & $\begin{array}{c}1.02 \\
(1.73)\end{array}$ & $\begin{array}{c}0.63 \\
(1.41)\end{array}$ \\
\hline
\end{tabular}

Panel D: Value weighted returns following UP (DOWN) lagged 12-month oil returns except low volatility anomaly

\begin{tabular}{|c|c|c|c|c|c|c|c|c|c|}
\hline \multicolumn{4}{|c|}{ UP } & \multicolumn{4}{|c|}{ DOWN } & \multicolumn{2}{|c|}{ UP-DOWN } \\
\hline Long (A) & Short (B) & A-B (C) & Alpha & Long (A) & Short (B) & A-B (D) & Alpha & C-D & Alpha \\
\hline $\begin{array}{c}0.73 \\
(1.16)\end{array}$ & $\begin{array}{c}-0.30 \\
(-0.41)\end{array}$ & $\begin{array}{c}1.03 \\
(3.42)\end{array}$ & $\begin{array}{c}1.17 \\
(4.73)\end{array}$ & $\begin{array}{c}1.44 \\
(1.85)\end{array}$ & $\begin{array}{c}1.60 \\
(1.66)\end{array}$ & $\begin{array}{c}-0.16 \\
(-0.32)\end{array}$ & $\begin{array}{c}0.59 \\
(1.40)\end{array}$ & $\begin{array}{c}1.19 \\
(2.08)\end{array}$ & $\begin{array}{c}0.58 \\
(1.13)\end{array}$ \\
\hline
\end{tabular}




\section{Appendix A: Computation of anomalies}

We compute the 12 anomalies as follows:

Net Stock Issues: Ritter (1991), Loughran and Ritter (1995), Fama and French (2008) and Pontiff and Woodgate (2008) show that returns are negatively related to net stock issues. At the beginning of each month $t$, we define net stock issues as the log ratio of split-adjusted shares (NOSH and AF) outstanding in month $t-1$ and shares outstanding in month $t-13$.

Composite Equity: Ritter (1991), Loughran and Ritter (1995) and Daniel and Titman (2006) show that returns are negatively related to composite equity issuance. At the beginning of each month $t$, we define composite equity issuance by subtracting the past 12-month cumulative stock return from the past 12-month growth in equity market capitalization (MV).

Momentum: Jegadeesh and Titman (1993) find that recent winners outperform recent losers. At the beginning of each month $t$, we compute the momentum formation period returns as the cumulative return over the months $t-12$ to $t-2$.

Accruals: Dechow et al. (1995), Sloan (1996) show that the firms with low accruals outperform the firms with high accruals. Following Sloan (1996), we define accruals as (annual change in current assets (WC02201) - annual change in cash and cash equivalents (WC02001) - annual change in current liabilities (WC03101) + annual change in short-term borrowing (WC03051) - annual depreciation, depletion and amortization expense in year $t$ $(\mathrm{WC} 01151) /(0.5 *$ total assets (WC02999) in year $t+0.5 *$ total assets in year $t-1)) . \mathrm{We}$ match accounting data of year $t-1$ with stock returns from July of year $t$ until June of year $t+1$.

Net Operating Assets: Hirshleifer et al. (2004) show that net operating assets scaled by total assets negatively predict returns. We define net operating assets as (operating assets operating liabilities) / one year lagged total assets, where operating assets $=$ total assets (WC02999) - cash and short-term investment (WC02001) and operating liabilities =total 
assets - short and long-term debt (WC03255) - minority interest (WC03426) - preferred stock and common equity (WC03995). We match accounting data of year $t-1$ with stock returns from July of year $t$ until June of year $t+1$.

Gross Profitability: Novy-Marx (2013) show that profitability positively predicts returns. We define gross profitability as (revenue minus cost of goods sold (WC01100) / total assets (WC02999)). We match accounting data of year $t$-1 with stock returns from July of year $t$ until June of year $t+1$.

Asset Growth: Cooper et al. (2008) show that total assets negatively predicts returns. We measure asset growth as the change in total assets of the previous fiscal year. We match accounting data of year $t-1$ with stock returns from July of year $t$ until June of year $t+1$.

Return on Assets: Fama and French (2006) show that return on assets (WC08326) positively predicts returns. We match accounting data of year $t-1$ with stock returns from July of year $t$ until June of year $t+1$.

Investment to Assets: Titman et al. (2004) and Xing (2007) find that scaled capital investments negatively predict returns. We compute investment-to-assets as (annual change in gross property, plant, and equipment (WC02301) + annual change in inventories (WC02101) / one year lagged total assets. We match accounting data of year $t-1$ with stock returns from July of year $t$ until June of year $t+1$.

Maximum daily return anomaly: Bali et al. (2011) show that stocks with the highest maximum daily returns underperform stocks with the lowest maximum daily returns in the subsequent month. At the beginning of each month $t$, we sort portfolios based on the maximum daily returns over the previous month, i.e., $t-1$ month.

Idiosyncratic risk anomaly: Ang et al. (2006) show that stocks with highest idiosyncratic volatility underperform stocks with the lowest idiosyncratic volatility in the subsequent 
month. At the beginning of each month $t$, we measure idiosyncratic risk as the standard deviation of the residual obtained from regressing a stock's excess return on Fama-French three risk factors over the past 36 months where at least 30 valid monthly returns are available. As a robustness check, we measure idiosyncratic risk based on market model and also daily data over the past 12 months and find same results.

Low volatility anomaly: Blitz and van Vliet (2007) and Baker, Bradley and Wurgler (2011) show that stocks with high volatility underperform stocks with the low volatility. At the beginning of each month $t$, we measure volatility as the standard deviation of monthly returns over the past 36 months where at least 30 valid monthly returns are available.

\section{Appendix B: Data screening}

We apply following filters that are suggested in the literature (e.g., Ince and Porter, 2006, Hou, Karolyi and Kho, 2011, Griffin, Kelly and Nardari, 2010) to clean DataStream data: 1. Exchanges, Security type, Currency: We include all the common stocks (TYP=EQ) traded at Shanghai stock exchange and Shenzhen stock exchange. Furthermore, we restrict our data to the primary quotation of security (ISINID=P); the security with the biggest market capitalization (MAJOR=Y), and traded in local currency, i.e., Chinese A-shares.

2. Filter non-common equity securities using security names: Restricting Type=EQ might not eliminate all non-common stocks (Ince and Porter, 2006). Therefore, following Lee (2011) and Karolyi et al. (2012), we manually examine company names to find non-common stocks, i.e., preferred stock, American Depositary Receipts (ADRs), mutual funds, index funds, warrants, investment trusts, Real Estate Investment Trusts (REITs) and other forms of non-common stocks. We exclude the stocks from our sample if the company name includes “ESPT”, “UNIT”, “TST”, “TRUST”, “INCOMEFD”, “INCOME FUND”, “UTS”, “RST”, “CAP.SHS”, "INV”, "HDG”, "SBVTG”, "VTG.SAS”, “GW.FD”, "VCT”, "RTN.INC”, 
“ORTF”, “HI.YIELD”, “PARTNER”, ”HIGH INCOME”, “INC.\&GROWTH”, “REIT”, “REAL EST", “GDR”, "PF”, "PREF”, "PRF”, “ADS”, and "INC.\&GW."

3. Filter data errors in returns: We apply several screening procedures to clean monthly return $\left(R_{t}\right)$ data estimated as suggested by Ince and Porter (2006) and others. First, we set any daily (monthly) returns as missing if the total return index for either day (month) $t$ or $t-1$ is less than or equal to 0.01 . Secondly, we set any daily (monthly) returns above $200 \%$ (300\%) as missing that is reversed within one month. More specifically, if daily (monthly) $R_{t}$ or $R_{t-1}$ is greater than $(200 \%) 300 \%$, and $\left(\mathrm{R}_{\mathrm{t}}+1\right)\left(\mathrm{R}_{\mathrm{t}-1}+1\right)-1<50 \%$, then we set both $\mathrm{R}_{\mathrm{t}}$ and $\mathrm{R}_{\mathrm{t}-1}$ as missing. Third, we winsorize monthly returns at the $0.1 \%$ and $99.9 \%$ level to reduce the impact of outliers. Finally, we also remove all monthly observations for delisted stocks from the end of the sample period to the first non-zero return since DataStream pads forward the last available data until the next valid value becomes available.

4. Filter by market capitalization: Ince and Porter (2006) suggest that return related errors are concentrated among small stocks. Therefore, we exclude observations for stocks with the market capitalization (MV) below the 20th percentile in the month of portfolio formation. Following Jacobs (2016) we also eliminate observations where MV of a stock is larger than $90 \%$ of the total market capitalization in that month.

\section{Appendix C: Construction of Fama-French three Factors}

The excess market return factor (RMRF)is the value-weighted market return for A-shares minus the one-month 30-day inter-bank offer rate. The SMB and HML factors are constructed using the six value-weighted portfolios formed on size and the book equity to market equity (BE/ME) ratio at the end of each June. Size is the market capitalization at the end of the June of year $y$ and BE/ME for June of year $y$ is the book equity for the last fiscal year ended in $y-1$ divided by ME for December of $y-1$. We exclude stocks with less than or equal to zero market capitalization and a negative BE/ME ratio to estimate SMB and HML 
factors. Following Fama and French (2012), we sort stocks into two size groups based on 90\% of the aggregate market capitalization as the breakpoint where the top (bottom) $90 \%$ (10\%) of aggregate market capitalization is classified as big (small). We also sort stocks into three $\mathrm{BE} / \mathrm{ME}$ portfolios based on 30th and 70th percentiles of BE/ME ratio where stocks above (below) the 70th (30th) percentile are classified as value (growth) stock. The intersection of size and $\mathrm{BE} / \mathrm{ME}$ portfolios result into six value-weighted portfolios. As in Fama and French (1993), SMB is the average return on the three small portfolios minus the average return on the three big portfolios whereas, HML is the average return on the two value portfolios minus the average return on the two growth portfolios. 